\title{
PENGARUH FAKTOR PERSONAL TERHADAP KOMITMEN ORGANISASIONAL GURU MADRASAH
}

\author{
Rofiq Faudy Akbar \\ Institut Agama Islam Negeri (IAIN) Kudus \\ rofiq@iainkudus.ac.id
}

\begin{abstract}
Abstrak
Penelitian ini bertujuan menguji pengaruh faktor personal terhadap komitmen organisasional. Faktor personal dalam penelitian ini diinterpretasikan dengan variabel job choice factor, expectancy, dan psikological contract. Responden penelitian adalah para guru madrasah swasta di Jawa Tengah Indonesia. Analisis data dengan menggunakan structure equation modelling - partial least square menunjukkan bahwa, faktor personal berpengaruh secara positif dan signifikan terhadap komitmen organisasional guru. Job choice factor merupakan pertimbangan pelamar pada saat pertama kali seseorang memutuskan untuk bekerja sebagai guru. Individu telah mengevaluasi gaji, sifat dari jenis pekerjaan sebagai pendidik, maupun prospek jangka panjang seperti kemungkinan untuk menjadi guru tetap sebuah madrasah/sekolah maupun peluang mendapatkan sertifikasi. Guru memiliki ekspektasi terkait kompensasi finansial dan non finansial serta berharap kepala madrasah/yayasan memberikan timbal balik atau apresiasi atas pengorbanan mereka terhadap organisasi. Guru mengharapkan respon positif dari kepala madrasah/yayasan, ketika beban pekerjaan mereka bertambah. Respon positif yang diberikan dari kepala madrasah/yayasan dapat meningkatkan komitmen mereka terhadap pekerjaan dan organisasi, demikian sebaliknya.
\end{abstract}

Kata Kunci : Faktor Personal, Guru Madrasah, Komitmen Organisasional

\begin{abstract}
This study aims to examine the influence of personal factors on organizational commitment. Personal factors in this study are interpreted with job choice factor, expectancy, and psychological contract variables. Research respondents were private madrasa teachers in the Central Java Indonesia. Data analysis using structural equation modeling partial least square shows that personal factors have a positive and significant effect on teacher organizational commitment. Job choice factor is the consideration of the applicant the first time someone decides to work as a teacher. Individuals have evaluated salary, the nature of the type of work as an educator, as well as long-term prospects such as the possibility to become permanent teachers of a madrasa / school and the opportunity to get certified. Teachers have expectations regarding financial and non-financial compensation and hope the head of the madrasa or foundation provides reciprocity or appreciation for their sacrifice to the organization. Teachers always expect a positive response from the head of the madrasalfoundation, as their workload increases. Positive responses from the head of the madrasa/foundation provided their commitment to work and organization will always increase, conversely.
\end{abstract}

Keywords: Personal Factors, Teacher of Madrasa, Organizational Commitment 


\section{A. Pendahuluan}

Salah satu ciri peradaban manusia yang bermasyarakat yaitu senantiasa ditandai dengan keterlibatannya dalam suatu organisasi tertentu (Thoha, 2008: 2). Organisasi dalam literatur Arab disebut dengan istilah at Tandzim, yang berarti keteraturan, kerapian, terkontrol yang diwujudkan pada kerja dalam satu jama'ah/kelompok. Para ahli mendefinisikan organisasi sebagai menentukan tindakan yang diperlukan untuk mencapai tujuan melalui pengaturan departemen, bagian, maupun unit-unit. Sedangkan menurut Taufiq organisasi adalah usaha mengkoordinasi anggota dengan tujuan untuk melaksanakan kebijakan yang telah ditetapkan dengan seefisien mungkin (Al Asy'ari, 2000: 173). Organisasi dalam pandangan Galbraith,dilihat sebagai kumpulan individu dan kelompok-kelompok. Interaksi dalam kumpulan individu dan kelompok tersebut dibuat terstruktur dan terkoordinasi untuk memfasilitasi pencapaian tujuan organisasi (Fisher, 2000: 113).

Manusia sebagai makhluk sosial memiliki kebutuhan untuk berinteraksi dengan manusia lain, berkumpul dalam populasinya, membentuk suatu kelompok masyarakat berikut struktur organisasi yang mengatur dan melindungi hak-hak mereka didalamnya. Masyarakat merupakan bentuk organisasi yang anggota dan struktur pengurusnya adalah anggota masyarakat itu sendiri. Organisasi dapat dipahami sebagai kumpulan individu-individu atau kelompok dengan tujuan tetentu, dan tak jarang tujuan-tujuan pribadi tersebut bertolak belakang dengan tujuan organisasi. Kehidupan manusia dalam organisasi sangatlah komplek karena melibatkan berbagai kepentingan yang ada di dalamnya, kepentingan organisasi itu sendiri, kepentingan kelompok dalam organisasi, dan kepentingan individu yang menjadi anggota organisasi.

Individu, kelompok, dan struktur merupakan unsur utama organisasi. Komitmen ketiganya dapat mempengaruhi efektivitas jalannya sebuah organisasi dan menjadi penentu tercapainya tujuan yang telah ditetapkan. Komitmen dalam Kamus Besar Bahasa Indonesia berarti kesepakatan; perjanjian untuk melakukan sesuatu kontrak atau tanggung jawab.Komitmen dalam bahasa Inggris berarti something that you have promise to do or loyalty, yaitu suatu kondisi ketika seseorang melaksanakan apa yang telah disepakati atau memberikan loyalitas 
terhadap organisasi. Sedangkan komitmen organisasional berarti kekuatan mengikat individu untuk melakukan suatu tindakanyang relevan dengansatu atau lebih tujuan. Pengertian ini sebagaimana dikemukakan oleh Meyer and Herscovitch bahwa komitmen organisasional adalah a force that binds an individual to a course of action of relevance to one or more aims. Para peneliti sebagaimana yang dikutip oleh Mowday, Steers, and Porter, menyebut komitmen organisasional sebagai "the psychological strengh of an individual's attachment to the organization"'(Slack, 2010: 421).

Menurut Steers dan Porter, komitmen organisasional dipengaruhi oleh tiga faktor utama yaitu; faktor personal, faktor organisasional, dan faktor nonorganizasional (Sopiah, 2008: 164). Husin, Hamid, dan Ruhana pernah melakukan penelitian tentang pengaruh faktor personal, organisasional, dan non-organisasional terhadap komitmen organisasional terhadap karyawan PT PLN (Persero) APJ Malang, hasil analisis menunjukkan bahwa terdapat pengaruh yang signifikan faktor personal terhadap komitmen organisasional karyawan.Penelitian ini selain mendeskripsikan mengenai faktor personal juga merupakan penelitian konfirmatori yang akan mengujikan ulang antara variabel personal dengan variabel komitmen organisasional pada objek penelitian dengan lokasi dan karakteristik yang berbeda. Penelitian ini dilakukan pada 90 orang guru madrasah swasta di wilayah Jawa Tengah.

\section{B. Pembahasan}

1. Faktor Personal

Faktor personal adalah faktor yang berasal dari internal pegawai/guru sebagai anggota organisasi. Steers dan Porter menjelaskan faktor personal ini dengan beberapa variabel lain seperti; job expectations, psychological contract, job choice faktor, dan personal character. Faktor personal dalam penelitian ini digambarkan dengan dimensi job expectations, psychological contract antara pegawai dan organisasi, dan job choice faktor. Expectation theory berawal dari ide-ide Tolman dan Lewin dalam meletakkan kerangka dasar bagi sejumlah teori motivasi yang menekankan pada peran ekspektasi dan valensi dalam menentukan perilaku. Para ilmuan pendukung teori ekspektasi ini diantaranya 
Adams, Atkinson, Edward, Locke, Peak dan Rotter, serta Vroom. Vroom merupakan orang pertama yang menerapkan konsep tersebut terutama untuk mengukur motivasi terhadap perilaku kerja.

Vroom mengemukakan bahwa teori ekpektasi, motivasi mendorong tindakan dan pilihan dari beberapa alternatif dipengaruhi oleh banyak faktor. Kekuatan faktor-faktor tersebut ditentukan oleh tiga unsur; valensi, ekspektasi, dan instrumentalitas (Erickson, 1995: 7). Valensi adalah pemenuhan atau antisipasi kepuasan dari berbagai penghasilan yang dimungkinkan, unsur ini berkaitan tetapi bukan sebagai nilai-nilai individu. Ekspektasi adalah keyakinan tentang kemungkinan tindakan-tindakan tetentu dapat memberikan penghasilan yang spesifik. Instrumentalitas merupakan asosiasi penghasilan-penghasilan yang berkaitan dengan kepercayaan seseorang bahwa penghasilan sekunder akan mengikuti penghasilan primer (Locke, Motowidlo, dan Bobko, 1986: 328).

Sebagai contoh, seorang pegawai mengusulkan tambahan insentif untuk kinerja, seperti tambahan bonus atau promosi. Pada ilustrasi tersebut, ekspektasi individu merujuk pada keyakinannya bahwa upaya memberikan tambahan penghasilan akan memperbaiki kinerja. Instrumentalitas lebih pada keyakinan bahwa dengan kinerja yang baik akan mendapatkan tambahan penghasilan, promosi, atau pengakuan prestasi. Valensi berkaitan dengan keyakinan bahwa tambahan penghasilan yang spesifik (bonus, promosi, pengakuan prestasi) akan memberikan kepuasan kepada individu, dimana masing-masing penghasilan memberikan tingkat valensi yang berbeda tergantung dari penilaian masingmasing individu. Teori Vroom tersebut mengindikasikan bahwa, tambahan penghasilan atau insentif dapat berfungsi sebagai motivator kinerja pada tingkat sejauh mana individu menghargai tambahan penghasilan yang diusulkan dan memiliki persepsi bahwa usaha mereka akan mendapatkan penghasilan tersebut (Erickson, 1995: 9).

Teori ekspektasi menyatakan bahwa kekuatan kecenderungan kita untuk bertindak dengan cara tertentu bergantung pada kekuatan ekspektasi kita mengenai hasil yang diberikan dan ketertarikannya. Teori Vroom ini memusatkan pada tiga hubungan yaitu: 
a. Hubungan upaya-kinerja

Probabilitas dirasakan oleh individu yang mengerahkan sejumlah upaya yang diberikan akan mengarahkan pada kinerja.

b. Hubungan kinerja-imbalan

Keadaan yang mana individu meyakini untuk melaksanakan pada suatu tingkat tertentu akan mengarahkan pada pencapaian hasil yang diinginkan.

c. Hubungan imbalan-tujuan pribadi

Keadaan yang mana imbalan organisasional akan memuaskan tujuan pribadi individu atau kebutuhan atau ketertarikan atas imbalan yang potensial tersebut bagi individu (Robbins dan Judge, 2015: 148-148).

Gambar: Hubungan Imbalan-Tujuan Pribadi

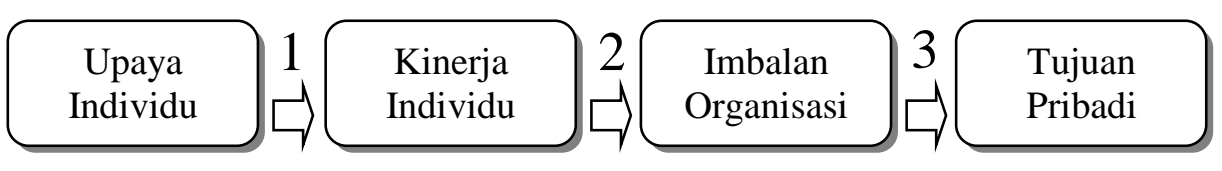

Sumber:Robbins dan Judge

Variabel personal faktor selanjutnya adalah kontrak psikologis, psychological contractmerupakan konsep berbasis hubungan antara karyawan dan organisasi yang pertama kali dikenalkan oleh Levinson, Price, Munden, Mandl, dan Solley pada tahun 1962, meskipun sebelumnya Argyris telah membahas beberapa konsep mengenai hal tersebut pada tahun 1960. Keduanya menjelaskan mengenai perasaan berkewajiban seorang karyawan terhadap organisasinya, dan perasaan berkewajiban organisasi untuk memberikan timbal balik kepada karyawan. Kotter merupakan orang pertama yang melakukan penelitian atas dasar teori tersebut pada 1973, akan tetapi sebenarnya Kotter mempelajari pentingnya sosialisasi karyawan baru tentang komitmen organisasional. Di awal tahun 1980-an para ilmuan masih berkutat dalam pendefinisian kontrak psikologis daripada melakukan penelitian lebih lanjut. Baru pada tahun 1985, McNeil mengemukakan sebuah teori dalam Wisconsin Law Journal tentang perbedaan antara kontrak relasional dan kontrak transaksional. Kemudian pada tahun 1990, Rousseau memfokuskan penelitiannya pada kontrak psikologis (Liao-Troth, 1999: 18). 
Kontrak psikologis disebut Rousseau sebagai teori kontrak modern (janji yang mengikat). Perjanjian ini mengikat semua pihak yang terlibat dan dapat ditemukan diantara para pendiri awal organisasi sosial manusia. Seperti budaya yang berkembang, orang-orang mulai mempelajari perjanjian dan kontrak yang mereka buat. Di zaman modern, kontrak telah dipelajari secara eksklusif oleh para ahli teori hukum (sebagai contoh digunakan dalam pengambilan keputusan hukum), atau oleh negosiator profesional (untuk lebih memahami bagaimana mencapai sebuah kesepakatan). Selama 20 tahun terakhir, perhatian penelitian telah cukup dicurahkan pada hubungan kerja antara karyawan dan organisasi, yang telah dijelaskan oleh banyak peneliti sebagai hubungan timbal balik (Blau 1964, Coyle-Shapiro et al. 2004, Mowday et al. 1982). Rousseau mendefinisikan kontrak psikologis sebagai keyakinan subyektif yang dipegang oleh individu mengenai syarat dan kondisi perjanjian timbal balik antara mereka dan manajer (orang yang memperkerjakan mereka) (Lapalme, Simard, dan Tremblay: 2010: 311-324).

Pada penelitian yang ia lakukan di tahun 1990, Rousseau menemukan fakta pendukung pada kedua jenis psikologi kontrak tersebut dengan melalui analisis korelasi kanonikal terhadap sikap 224 mahasiswa MBA dalam proses pencarian pekerjaan. Sebagai subyek yang diwawancarai dan akan bergabung dengan organisasi, mereka menerima janji yang dibuat sebagai kontrak psikologis bagi mereka. Penemuan tersebut menjelaskan, bahwa tidak semua mahasiswa MBA ingin digaji tinggi sebagai timbal balik dari kerja keras mereka (kontrak psikologis transaksional). Beberapa sampel lebih menginginkan kontrak psikologis relasional dengan perusahaan dan mereka menemukan hal tersebut pada perusahaan (Liao-Troth, 1999: 19-20).

Konsep kontrak psikologis dibangun berdasarkan teori pertukaran sosial (social exchange theory), dimana menurut Blau, Tekleab, dan Chiaburu, orang termotivasi untuk menjaga keseimbangan antara input dan output ketika mencari timbal balik dalam transaksi sosial. Akan tetapi pertukaran sosial menurut Blau tidak spesifik dan bervariasi, dengan demikian mata uang dan mekanisme yang digunakan individu untuk mengukur pertukaran dalam kontrak psikologis 
cenderung tidak jelas. Cropanzano dan Mitchell menyatakan, standar ukuran pertukaran sosial dalam hubungan kerja bisa berupa satu atau lebih dari berbagai kewajiban dan atau berbagai fokus usaha (Rodwell dan Ellershaw, 2015: 232247).

Meyer et. al. mengatakan bahwa sangat penting memahami kontrak psikologi dalam kaitannya dengan tujuan yang ingin dicapai organisasi. Jenis kontrak psikologis manakah yang berpengaruh, dimana karyawan memutuskan untuk meninggalkan atau tetap menjadi anggota organisasi. Porter at. al. menambahkan, perlu diketahui juga apakah karyawan menerima nilai-nilai dan tujuan organisasi dan seberapa banyak usaha seorang karyawan akan dihargai. Kontrak psikologi memiliki korelasi dengan komitmen organisasional karyawan, sebagaimana disebutkan Philipp (2012: 2) dalam penelitian yang ia lakukan bahwa kontrak transaksional memiliki hubungan positif dengan komitmen afektif, normatif dan kontinyu. Demikian pula dengan penelitian Jing, Lin Xie, dan Ning(2014: 1098), menyebutkan bahwa kontrak psikologi relasional memiliki korelasi positif terhadap perubahan komitmen normatif.

Pilihan pekerjaan (job choice faktor), juga merupakan dimensi dari faktor personal. Kerangka pikir untuk memahami faktor pilihan pekerjaan (job choice factors) diperoleh dari perspektif teoritis pada pilihan (choice) dan pengembangan karier (career development). Barber menjelaskan bahwa pilihan pekerjaan (job choice) adalah proses pengambilan keputusan yang dinamis dimana pencari kerja bergerak melalui berbagai tahapan pengambilan keputusan. Turban et. al. menambahkan, faktor penting bagi individu seperti berbagai tahapan yang berbeda dalam mencari pekerjaan dan proses menentukan pilihan sebagai pelamar, akan lebih memperhatikan pada tersedianya peluang dan preferensi pekerjaan yang mereka pilih (Boswell, et. al., 2003: 23). Riset-riset empiris telah meningkatkan pemahaman secara signifikan mengenai bagaimana orang memutuskan dimana akan bekerja dan mengembangkan pengetahuan mengenai job choice faktors theory. 
Behling et al., menguraikan tiga hal yang berkaitan dengan pengambilan keputusan individu selama proses untuk mencari pekerjaan. First, pengambilan keputusan pelamar dipengaruhi oleh item-item yang nyata dan dapat diamati. Para pelamar diasumsikan telah mengevaluasi gaji, sifat dari berbagai jenis pekerjaan, prospek jangka panjang dan pendek untuk kemajuan terkait dengan setiap posisi dan berbagai faktor lainnya. Second,pengambilan keputusan pelamar dipengaruhi oleh persepsi mereka mengenai lingkungan kerja dan persepsi mengenai kemampuan perusahaan untuk memberikan kepuasan bagi kebutuhan emosional terpendam pelamar yang sering tidak diungkapkan. Third, pengambilan keputusan pelamar dipengaruhi oleh individu yang dihadapi dalam proses pencarian kerja. Pelamar mempertimbangkan penampilan dan perilaku perekrut, sifat fasilitas fisik madrasah/perusahaan (Heikkila, 2005: 21).

Teori pemilihan pekerjaan telah diteliti dalam konteks pendidikan oleh Pounder \& Merrill pada tahun 2001, Young \& Heneman di 1986 dan Young, Rinehart, \& Place pada tahun 1989. Sebuah studi terkontrol juga dilakukan oleh Young \& Heneman, penelitian tersebut mengobservasi calon guru dalam wawancara tiruan untuk menentukan faktor-faktor yang akan mempengaruhi pengambilan keputusan dalam pemilihan posisi (Heikkila, 2005: 22).Boswell merumuskan beberapa indikator dari job choice faktor dengan mengacu pada kesamaan konseptual seperti; lingkungan menyenangkan dan bersahabat yang dicerminkan dari budaya perusahaan atau dimensi dari general construct seperti; pengganti biaya kuliah, jaminan kesehatan yang kedua hal tersebut mencerminkan manfaat atau keuntungan (Boswell, et. al., 2003: 37).

2. Metode Penelitian

Penelitian ini menggunakan metode kuantitatif, yaitu penelitian yang memerlukan studi pada sampel, populasi, dan sangat bergantung pada data numerik dan analisis statistik. Kebanyakan penelitian kuantitatif dilakukan oleh peneliti yang menganut epistemologi positivisme (Gall, 2010: 15). Structure Equation Modelling-Partial Least Squaremengasumsikan bahwa semua ukuran varian adalah varian yangberguna untuk dijelaskan sehingga pendekatan estimasi variabel laten dianggap sebagai kombinasi linear dari indikator dan 
menghindarkan masalah factor indeterminacy (ketidakpastian) (Ghozali, 2010: 5-6). Analisis dengan menggunakan SEM-PLS menekankan pada identifikasi varians dan konstruksi hubungan antar variabel yang memungkinkan eksplorasi dan akomodasi pada model pengukuran yang kompleks. Hal ini sebagaimana yang dikemukakan oleh Chin dan Barclay et al. dalam penelitiannya menyatakan, "its emphasis dwells on identifying the variance and relationships between constructs and variables. This permits the exploration of the data and accommodation of complex theoretical and measurement models" (Dino dan Guzman, 2015: 53).

3. Pengaruh Faktor Personal Terhadap Komitmen Organisasional Guru

Analisis data dengan menggunakan SEM-PLS setidaknya harus melalui lima proses tahapan, dimana setiap tahapan yang dilakukan akan menentukan pengaruh terhadap tahapan selanjutnya. Tahapan-tahapan tersebut meliputi; tahap konseptualisasi model, tahap menentukan metode analisis algoritma, tahap menentukan metode resampling, tahap menggambar diagram jalur, dan tahap evaluasi model. Tahapan-tahapan tersebut perlu dilakukan sebelum analisis lebih lanjut untuk memastikan masing-masing elemen valid dan dapat diandalkan dalam setiap evaluasi sebelum membangun hubungan antar konstruksi. Sebagaimana yang diutarakan Barclay et al., this ensures valid and reliable elements in each construct prior evaluation of the relationships among the constructs(Dino dan Guzman, 2015: 68).

a. Konseptualisasi model

Spesifikasi domain konstruk dilakukan dengan menentukan variabelvariabel penelitian yang terdiri dari variabel eksogen dan variabel endogen. Faktor personal disebut sebagai variabel eksogen dan selanjutnya komitmen organisasional disebut sebagai variabel endogen. Penentuan item yang merepresentasi konstruk dilakukan dengan; menyusun indikator-indikator variabel, uji pre-test untuk menguji validitas kuesioner, pengembangan teori sebagai bentuk purifikasi konstruk, pengumpulan data dilakukan setelah kuesioner tersusun rapi, dan skor pengukuran konstruk ditentukan 
menggunakan skala 1-4 dengan empat pilihan jawaban, kemudian uji validitas dan reliabilitas akan dilakukan setelah data terkumpul pada tahapan evaluasi model.

b. Metode Analisis Algorithma

Tahapan selanjutnya menentukan metoda analisis algorithma apa yang akan digunakan untuk estimasi model. Dalam SEM-PLS, metoda analisis algorithma yang disediakan adalah factorial, centroid dan path atau struktural weighting. Sebagaimana yang telah diketahui bahwa prinsip dasar PLS-SEM tidak menuntut sampel dalam jumlah besar, sampel yang direkomendasikan antara 30 sampai 100 kasus atau sebagaimana yang dikemukakan oleh Chin, jumlah sampel PLS dihitung dengan cara sepuluh kali jumlah variabel dalam model (Latan dan Ghozali, 2012: 52). Adapun sampel dalam penelitian ini ditentukan sebanyak 99 sampel dari guru madrasah yang ada di Jawa Tengah.

c. Menentukan Metode Resampling

Setelah melakukan konseptualisasi model dan menentukan metoda analisis algorithma, langkah selanjutnya adalah menentukan metoda resampling. Terdapat dua metoda yang digunakan oleh peneliti di bidang SEM untuk melakukan proses penyempelan kembali (resampling) yaitu, bootstrapping dan jacknifing. Proses resamplingdalam analisis ini menggunakan metoda bootstrapping. Bootstrapping bertujuan untuk mengetahui probabilitas dari nilai uji statistik pada berbagai tingkatan/interval. Penelitian ini menggunakan metoda resampling pertama yaitu pilihan item no sign changes pada menu bootstrapping. Menurut Tenenhaus et. all., metode standar resampling adalah no sign changes yaitu statistika resampling yang dihitung tanpa mengkompensasi tanda apapun. Pilihan ini sangat konservatif karena menghasilkan standar error yang sangat tinggi namun konsekuensinya rasio T-statistik menjadi rendah. 
d. Path Diagram

\section{Path Diagram}

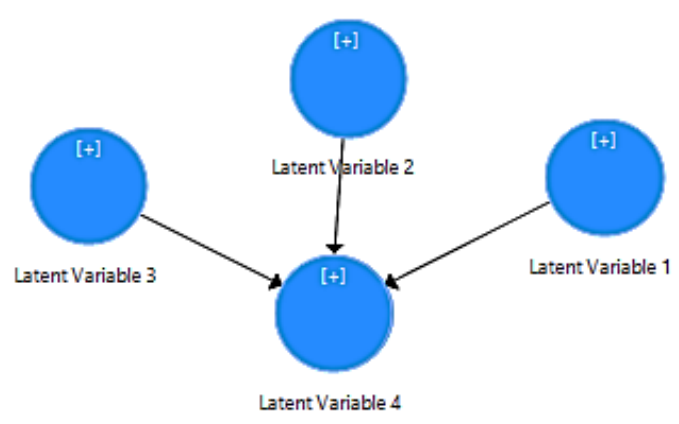

e. Evaluasi Model

Evaluasi model dalam SEM-PLS dapat dilakukan dengan dua cara yaitu; pengukuran outer model untuk menilai hasil pengukuran model (measurement model) dengan menguji validitas dan reliabilitas konstruk (assessment of the reliability and validity of the measures). Kemudian dilanjutkan dengan evaluasi model struktural atau inner model untuk memprediksi hubungan antar variabel laten. Sebagaimana yang diungkapkan oleh Barclay et. al., bahwa model analisis SEM-PLS terdiri dari dua tahapan, (a) assessment of the reliability and validity of the measures, and (b) assessment of the structural model(Dino dan Guzman, 2015: 60).

Uji validitas indikator refleksif dapat dilihat dari nilai loading factor untuk tiap indikator konstruk. Dalam model variabel diatas diketahui bahwa nilai loading factor dari semua manifest variablediatas 0,7 yang berarti memenuhi syarat validitas. Demikian pula dengan nilai AVE yang ada didapati lebih dari 0,50. Konstruk juga dinyatakan memenuhi syarat reliabilitas dari nilai composite reliability dan cronbach's alpha diatas 0,70.

Setelah memenuhi syarat validitas dan reliabilitas, maka model dapat digunakan untuk analisis selanjutnya yaitu uji hipotesis apakah terdapat pengaruh faktor personal terhadap komitmen organisational guru. Pengujian terhadap model struktural dilakukan dengan melihat nilai R-square yang 
merupakan uji goodness-fit model. Model pengaruh faktor personal terhadap komitmen organisasional guru memberikan nilai R-square sebesar 0,276, sehingga dapat diinterpretasikan bahwa faktor personal memberikan pengaruh terhadap komitmen organisasional guru sebesar $27,6 \%$ sedangkan $72,4 \%$ lainnya dijelaskan oleh variabel lain diluar variabel yang diteliti.

Faktor personal berpengaruh secara positif terhadap komitmen organisasional guru. Hal ini berdasarkan hasil interpretasi algoritma bootstrappingdengan melihat pada nilai koefisien paramater yang menunjukkan angka positif 0,525 dan nilai signifikansi t-statistik 2,783 lebih besar dari nilai t-tabel. Semakin tinggi faktor personal maka semakin tinggi komitmen organisasional guru.

\section{Bootstrapping Algorithma Result}

\begin{tabular}{lrrr}
\hline & Path Coeffcients & RSquare & T Statistics \\
\hline $\begin{array}{l}\text { Bootstrapping } \\
\text { Algorithma }\end{array}$ & 0,855 & 0,276 & 2,783 \\
\hline
\end{tabular}

\section{Simpulan}

Banyak teori yang telah dikemukakan oleh para ahli bahwa ekspektasi berpengaruh terhadap motivasi dan perilaku. Salah satu ahli yang pertama kali berhasil mengidentifikasi pentingnya ekpektasi adalah Tolman ketika ia memperkenalkan teori aspek kognitif pembelajaran pada tahun 1932. Berbeda dengan teori pembelajaran behavioristik yang populer saat itu, Tolman menyatakan bahwa baik manusia atau hewan memiliki pengetahuan mengenai tujuan dan ekspektasi berdasarkan perilaku yang mereka tunjukkan. Berdasarkan penjelasan Tolman, ekspektasi melibatkan pengetahuan mengenai hubungan antara dan diantara stimulus/rangsangan dan respon. Begitu pula dengan Lewin yang mendeskripsikan motivasi sebagai pilihan kognitif diantara beberapa alternatif, menekankan pada peran aspirasi individu, ekspektasi, dan pengaruh. Lewin juga mengatakan bahwa ekspektasi sangat berpengaruh terhadap persepsi individu. 
Sedangkan kontrak psikologis didefinisikan Rousseau sebagai keyakinan subyektif yang dipegang oleh individu mengenai syarat dan kondisi perjanjian timbal balik antara mereka dan manajer/kepala madrasah/institutsi. Lebih lanjut Rousseau menyatakan kontrak psikologis adalah kontrak yang dibangun di dalam mindset seorang karyawan, berdasarkan persepsi mereka tentang masalah ketenagakerjaan yang telah disepakati, disamping berbagai kontrak formal yang ada. George dan Jones menjelaskan bahwa kontrak transaksional diterapkan dalam jangka pendek dengan fokus yang sempit. Dalam kontrak transaksional individu lebih fokus pada hasil ekstrinsik seperti gaji atau tunjangan dan bukan pada hasil intrinsik, seperti kepuasan kerja atau penerimaan di tempat kerja. Kontrak relasional berbasis manfaat jangka panjang dan memberikan hasil yang baik secara intrinsik maupun ekstrinsik.

Ekspektasi dan kontrak psikologis merupakan rangkaian proses yang terjadi semenjak sesorang memilih pekerjaan yang akan dijalaninya. Sebagaimana dijelaskan oleh Boswell et. al., bahwa pada proses menentukan pilihan sebagai pelamar akan lebih memperhatikan pada tersedianya peluang dan preferensi pekerjaan yang mereka pilih.Pengambilan keputusan pelamar dipengaruhi oleh item-item yang nyata dan dapat diamati. Para pelamar diasumsikan telah mengevaluasi gaji, sifat dari berbagai jenis pekerjaan, prospek jangka panjang dan pendek untuk kemajuan terkait dengan setiap posisi dan berbagai faktor lainnya. Keputusan pelamar dipengaruhi oleh persepsi mereka mengenai lingkungan kerja dan persepsi mengenai kemampuan perusahaan untuk memberikan kepuasan bagi kebutuhan emosional terpendam pelamar yang sering tidak diungkapkan. Pelamar mempertimbangkan penampilan dan perilaku perekrut, sifat fasilitas fisik perusahaan, dan efisiensi dalam pengolahan kertas kerja yang terkait dengan permohonannya.

Faktor personal yang diinterpretasikan dari ekspektasi, kontrak psikologis, dan job choice factor dapat berpengaruh terhadap komitmen organasional guru. Job choice factor merupakan pertimbangan pelamar pada saat pertama kali seseorang memutuskan untuk bekerja sebagai guru. Individu telah mengevaluasi gaji, sifat dari jenis pekerjaan sebagai pendidik, maupun prospek jangka panjang seperti 
kemungkinan untuk menjadi guru tetap sebuah madrasah/sekolah maupun peluang mendapatkan sertifikasi. Kemajuan terkait dengan setiap posisi dan berbagai faktor lainnya dengan pertimbangan peluang karier yang ada pada madrasah tersebut. Halhal yang menjadi pertimbangan di awal pekerjaan tersebut kemudian menjadi ekspektasi guru terhadap profesi yang dijalaninya, sehingga setiap beban pekerjaan yang berlebih secara normatif akan menumbuhkan kontrak psikologis antara guru dengan kepala madrasah atau yayasan.

Guru memiliki ekspektasi terkait kompensasi finansial dan non finansial serta berharap kepala madrasah atau yayasan memberikan timbal balik atau apresiasi dari setiap pengorbanan yang mereka berikan terhadap madrasah atau organisasi. Sebagaimana telah dijelaskan para peneliti seperti Robbins, Timothi, dan Sanghi bahwa komitmen organisasional adalah sikap kerja (Lissy T. A. dan Vankatesh, 2014: 198), O'Reilly and Chatman mendefinisikan sebagai the psychological commitment felt for the organization by the individual,sertaAllen dan Meyer yang memberikan definisi komitmen organisasional sebagai psychological state describing the relations of employees with the organization and referred to their decisions to stay in the organization (Sirin, Bilir, dan Karademir, 2013: 65), maka segala hal yang berkaitan dengan personal guru akan mempengaruhi sikap kerja dan perasaan mereka terhadap organisasi. Guru mengharapkan respon positif dari kepala madrasah/yayasan, dengan begitu komitmen mereka terhadap pekerjaan dan organisasi akan selalu meningkat. Demikian sebaliknya jika para guru mendapatkan respon negatif dari kepala madrasah/yayasan, maka hal tersebut dapat menurunkan komitmen organisasional mereka. 


\section{Daftar Pustaka}

Miftah Thoha, Perilaku Organisasi, Konsep Dasar Dan Aplikasinya (Raja Grafindo Persada, 2008).

Ahmad bin Daud Al Mizjajy Al Asy'ari, Mukaddimah Al Idharah Al Islamiyah (King Abdul Aziz University, 2000).

Fisher, Susan, "Multilevel Theory of Organizational Performance," Dissertation, UMI Number: 9987335, (Oklahoma State University, 2000).

Frederick J.Orife, "Effects of Commitment to Corporate Vision on Employee Satisfaction with Their Organization," (International Journal of Management 27, no. 3 2010)

Sopiah, Perilaku Organisasional (Penerbit Andi, 2008).

Anna Rebekah Erickson, "Expectations and Job Search Behavior Among Graduating University Seniors” (Iowa State University, https://doi.org/10.1016/j.jorganchem.2010.09.058.

Edwin A. Locke, Stephan J. Motowidlo, and Philip Bobko, "Using Self-Efficacy Theory to Resolve the Conflict Between Goal-Setting Theory and Expectancy Theory in Organizational Behavior and Industrial/Organizational Psychology," Journal of Social and Clinical Psychology 4, no. 3 (1986): 328-38, https://doi.org/10.1521/jscp.1986.4.3.328.

Stephen P. Robbins and Timothy A. Judge, Perilaku Organisasi, Organizational Behavior," Alih Bahasa: Diana Angelica, Dkk. (Salemba Empat, 2015).

Matthew Allen Liao-Troth, "The Psychological Contract of Volunteer Workers and Its Consequences" (University of Arizona, 1999).

Marie Ève Lapalme, Gilles Simard, and Michel Tremblay, "The Influence of Psychological Contract Breach on Temporary Workers' Commitment and Behaviors: A Multiple Agency Perspective," Journal of Business and Psychology 26, no. 3 (2011): 311-24, https://doi.org/10.1007/s10869-010-9190-5.

John Rodwell and Julia Ellershaw, "What Is Exchanged in Psychological Contracts? Multiple Sets of Obligations, Targeted Effort and Uncertainty Reduction," Employee Relations 37, no. 2 (2015): 232-47, https://doi.org/10.1108/ER-06-2014-0075.

Beverly L U Philipp, "Psychological Contracts in the Workplace: Relationships among Organizational Commitment, Organizational Citizenship Behaviors, and Ethical Leadership.," Dissertation Abstracts International Section A: Humanities and Social Sciences (Alliant International University, 2013), http://gateway.proquest.com/openurl?url_ver=Z39.88-

2004\&rft_val_fmt=info:ofi/fmt:kev:mtx:dissertation\&res_dat=xri:pqm\&rft_dat=xri:pqd iss:3523554\%5Cnhttp://ovidsp.ovid.com/ovidweb.cgi?T=JS\&PAGE=reference \&D=psy c10\&NEWS=N\&AN=2013-99131-110.

Runtian Jing, Jia Lin Xie, and Jing Ning, "Commitment to Organizational Change in a Chinese Context," Journal of Managerial Psychology 29, no. 8 (2014): 1098-1114, https://doi.org/10.1108/JMP-08-2011-0042. 
Wendy R. Boswell et al., "Individual Job-Choice Decisions and the Impact of Job Attributes and Recruitment Practices: A Longitudinal Field Study," Human Resource Management 42, no. 1 (2003): 23-37, https://doi.org/10.1002/hrm.10062.

Kenneth R. Heikkila, "The First Principalshio: Job Choice Theory in Principal Candidate Decision Making" (Seattle University, 2005).

Meredith D. Gall, Applying Educational Research: How to Read, Do, and Use Research to Solve Problem Of Practice (Pearson Education Inc., 2010).

Hengky Latan and Imam Ghozali, Partial Least Squares Konsep, Teknik, Dan Aplikasi Menggunakan Program SmartPLS 2.0 M3, Untuk Penelitian Empiris (Semarang: Badan Penerbit Universitas Diponegoro, 2012).

Michael Joseph S. Diño and Allan B. De Guzman, "Using Partial Least Squares (PLS) in Predicting Behavioral Intention for Telehealth Use among Filipino Elderly," Educational Gerontology 41, no. 1 (2015): 53-68, https://doi.org/10.1080/03601277.2014.917236.

Latan and Ghozali, Partial Least Squares Konsep, Teknik, Dan Aplikasi Menggunakan Program SmartPLS 2.0 M3, Untuk Penelitian Empiris.

Lissy. T. A and J. Venkatesh, "Factors That Influence the Organizational Commitment - A Case of Paramedical Staff at Private Hospitals," International Journal of Multidisciplinary Approach and Studies 01 (2014): 195-206.

Yeliz Sirin, Pervin Bilir, and Tamer Karademir, "The Effect of Organizational Commitment on Job Performance: The Case of the Kahramanmaras Provincial Directorate of Youth Services and Sports," International Journal of Academic Research 5, no. 4 (2013): 6571, https://doi.org/10.7813/2075-4124.2013/5-4/B.9. 